Література

1. Державна служба статистики України [Електронний ресурс]. - Режим доступу: http://www.ukrstat.gov.ua/

2. Економічний аналіз: навчальний посібник/Г. П. Голубнича, Л. І. Панасенко. -К.: Вид.-полігр. центр "Київський університет", 2008. -309 с.

3. Гура Н.О. Облік видів економічної діяльності: Підручник / Н.О. Гура. Київ: Центр учбової літератури, 2010. - 391 с.

Стаття відправлена: 21.03.2017 p.

(C) Ревенко К.О.

\author{
ЦИТ: иа117-105
}

DOI: 10.21893/2415-7538.2016-05-1-105

УДК 339.13:332.1

\title{
ФОРМИРОВАНИЕ КОНКУРЕНТНОЙ СРЕДЫ НА РЕГИОНАЛЬНОМ ПОТРЕБИТЕЛЬСКОМ РЫНКЕ: ИННОВАЦИИ, СТРАТЕГИИ, ИНСТРУМЕНТЫ
}

Белгородский университет кооперации, экономики и права, Белгород, ул. Садовая, 116, «А»

Meshechkina R.P., Lysova I.I.

\section{FORMATION OF COMPETITIVE ENVIRONMENT IN THE REGIONAL} CONSUMER MARKET: INNOVATIONS, STRATEGIES, TOOLS Belgorod University of Cooperation, Economics and Law, Belgorod, Sadovaya, 116, "A"

Аннотация. В статье излагаются проблемь развития регионального потребительского рынка, возможность и необходимость использования для портфельного анализа матричных методов, выступающего основой разработки перспективного плана развития торговой компании с учетом тендениий, сложившихся на региональном потребительском рынке, приводятся инструменты инновационной стратегии формирования рыночных условий и конкурентной среды на региональном потребительском рынке.

Abstract. The article deals with the problems of the regional consumer market development; investigates the possibility and necessity of using matrix methods for portfolio analysis, which is the basis for working out a trading company's long-term development plan under the trends dominating in the regional consumer market; studies the innovation strategy tools for the both market conditions and a competitive environment formation at the regional consumer market.

Ключевые слова: потребительский рынок, торговая компания, конкурентная среда, инновационная стратегия, потребители, ассортимент, маркетинговые инструменты.

Key words: consumer market, trading company, competitive environment, innovative strategy, consumers, range of goods, marketing tools.

Introduction. In order to ensure a stable and efficient operation of the trading company it is necessary to monitor the situation at the regional consumer market, 
including identification of the territorial boundaries; to assess the consumer market capacity; to determine the trading company's market share; to find out the level of competition and the consumer market development tendencies. For this purpose a special attention should be given to: the portfolio analysis of the strategic product lines based on $\mathrm{ABC}$ analysis, product life cycle stages, matrix portfolio analysis techniques such as the BCG matrix, the MCC matrix, the GE / McKinsey matrix and other methods; using SWOT-analysis; working out a long-term forecast of the trading company's development; taking into account the existing competitive environment of the regional market.

Main text. The competitor analysis and assessment of the trading company's competitiveness in the regional consumer market make it possible to identify competitors, assess their market share, determine the rival trading companies' objectives and their marketing strategy, assess their strengths and weaknesses, the range of possible reactions of competing firms in the consumer market, categorize them from both the perspective of the maximum threats they constitute and the possibility of ignoring their presence in the regional market.

When you are positioning the trading company in the regional consumer market the following trends should be considered:

- relative saturation of the consumer market by the network trade;

- ongoing regional expansion of the consumer market of large retail trade enterprises;

- ongoing consolidation of the industry;

- acquisition of local trade enterprises by large-scale trading networks in various regions of Russia;

- increase of new formats' share in the consumer market (hypermarkets, supermarkets, discounters) in the total of retail trade in comparison with traditional formats;

- development of the "multi-format" strategy by large retail trade networks in order to retain market share, attract new customers and preserve the existing consumer environment;

- escalation of conflicts between retail chains and product suppliers [1, p. 14].

Formation of the market conditions and competitive environment in the regional consumer market should be based due to the possibility to provide the trading company with the maximum leadership position. For this purpose it is advisable:

- to actively search for regional markets with solvent demand for the selling product line;

- to increase marketing tools effectiveness for mounting customers' loyalty to the trading company;

- to take full advantage of attracting advertising agencies and mass media as partners and manufacturers, who are delivering "branded" products and serving regular customers in the defined region, as suppliers;

- to diversify the range of selling products and, on this basis, improve the quality and competitiveness of the trading company;

- to use innovative approaches for solving strategic tasks on the trading company's positioning, carrying out communication management, choosing a proper brand development strategy. 
A large trading producer, which is positioning the company in the regional consumer market, should take advantage of the most effective tools for creating a competitive environment. The following actions can be undertaken:

- to manufacture promotional items - pens, lighters, calendars - for handing them round to representatives of retail trade enterprises;

- to release stickers;

- to use corporate trademarks and logos;

- to give advertisements in newspapers and industry publications;

- to participate in international trade fairs.

International exhibitions are one of the most effective marketing tools for increasing sales and expanding the market segment at the consumer market.

Conclusion and conclusions. Participation in such activity allows the trading company to advertise its trade enterprises to a sufficiently large number of visitors, partners and suppliers, to give more details about the range of selling products, to inform about the prospects for development. Successful participation in fair and exhibition activities, in addition to searching for potential buyers, also provides an opportunity to get acquainted with the competitors' advantages and collect information on the trends that are currently dominating in the market.

\section{References:}

1. Isaenko E.V., Degtyar O.N. Attraction of Buyers in Retail Chains on the Basis of Marketing Technologies [Text] // E.V. Isaenko, O.N. Degtyar // Bulletin of Belgorod University of Cooperation, Economics and Law. - 2016. - №4 (60). - Pp. 920. UDC 339.37.:339.138. ISSN 2223-5639. DOI 10.21295/2223-5639-2016-4-9-23

2. Meshechkina R.P., Shilenko S.I. Use of Information and Communication Capacities of Chain Retail CRM Systems as an Innovative Tool for Loyalty Programs Development [Text] / R.P. Meshechkina, S.I. Shilenko // Bulletin of Belgorod University of Cooperation, Economics and Law. - 2016. - № 1 (57). - Pp. 16-24. УДК 339.37:004. ISSN 2223-5639.

3. Meshechkina R.P., Shilenko S.I. Regional Development of Innovative Infrastructure as a Factor for Stimulating Exporting of High-tech Products [Text] / R.P. Meshechkina, S.I. Shilenko // Scientific journal "Discourse" - 2016 - № 1. Pp. 319-329.

Article sent date: 07.04.2017

(C) Meshechkina R.P.

\section{ЦИТ: иа117-133}

DOI: 10.21893/2415-7538.2016-05-1-133

УДК 338.583

УПРАВЛІННЯ ВИРОБНИЧИМИ ЗАТРАТАМИ

Мельник О.В.

НА ОСНОВІ УДОСКОНАЛЕННЯ ЗАБЕЗПЕЧЕННЯ

СІЛЬСЬКОГОСПОДАРСЬКОГО ПІДПРИЕМСТВА ВИРОБНИЧИМИ РЕУРСАМИ

Вінницький національний аграрний університет, Вінниия, Сонячна 3, 21008 